\title{
"Blood Suckers Most Cruel:" The Vampire and the Bat In and Before Dracula
}

\author{
Kevin Dodd*
}

\begin{abstract}
The relationship between the nineteenth century vampire monster and the vampire bat has not yet been seriously investigated in English. Three common assumptions made by experts are examined in this paper. Current vampire historiography has held that Stoker's use of a huge bat as the vampire was either mistaken or a creative innovation and therefore requires explanation in those terms. It supposes that people in the nineteenth century understood the word "vampire" the way we do today. It presumes Dracula to be the first story to have a vampire monster transform into a bat. To consider these positions, we must first analyze the use of the bat in Dracula and then set it in the context of 19th-century conceptions of the vampire bat to see how mistaken or creative Stoker actually was. Thereafter a survey of 19th-century works that are said to be leading the way to Dracula is initiated to see if "vampire" had the same meaning then as it does today. Finally we will examine if Dracula's metamorphosis from a monster into a vampire bat had any precursors and, if so, how distinctive Stoker was in developing it.
\end{abstract}

\section{Introduction}

Study of the vampire as an artifact of popular, and even of high culture in the $19^{\text {th }}$ century is, in several ways, arrested. It has its topoi, its familiar places, especially concerning vampires and bats, to which researchers regularly return and assume the validity of their consensus. I want, in this paper, to introduce three areas that need careful reconsideration. I will pose them as questions. Does the nineteenth century use the word "vampire" the way we use it today or do we project our ideas back on to it? How did the $19^{\text {th }}$ century understand the vampire bat? Was it the microbat we designate today or was it something else entirely? Finally, how did it work out the relationship between the vampire monster and the vampire bat? Were the two commonly conflated, but awaited Bram Stoker's Dracula before they could transform into each other? Or was a blurring between them relatively rare, with mutual metamorphosis, equally uncommon, nonetheless preceding the book?

\section{The Bat in Dracula}

The vampire is a complex shapeshifter in Dracula. ${ }^{1}$ There are four types in evidence: two are dispersive-to particulate matter and to vapor; two are concrete - to a wolf and, of course, into a bat.

\footnotetext{
${ }^{*}$ Visiting Scholar, Vanderbilt University, USA.
} 
The bat is the primary way Dracula approaches Lucy and may be the predominant way he feeds on her as well. There are ten mentions of a large bat in the context of Lucy, several times emphasizing the flapping, scratching, buffeting, and striking of its wings against the window, which at times appear to have an almost hypnotic effect. ${ }^{2}$ One reference is by Quinsey Morris where he compares Lucy's precipitous decline with that of a horse he saw in the plains of South America drained of its blood "from those big bats that they call vampires."3 She dies with a great bat circling around outside.

Afterward, disappearances of children are reported; they are found alive, but they have marks on their throats. Van Helsing prepares for his revelation that the postmortem Lucy is responsible by reminding his audience of nocturnal bats that "open the veins of cattle and horses and suck dry their veins" and others which flit down on sleeping sailors and take their lives. ${ }^{4}$ The attending physician of one of the victims conjectures the child was bitten by a bat: "Out of so many harmless ones ... there may be some wild specimen from the South of a more malignant species. Some sailor may have brought one home, and it managed to escape, or even from the Zoological Gardens a young one may have got loose, or one be bred there from a vampire."5

With the vampire Lucy dispatched, Van Helsing explains to the five that comprise the group of would-be slayers as much information as he can about Dracula, including the fact he can appear as a bat. As discussion ensues, Quincey leaves and a pistol shot rings out. Quincey had left the building and fired at a "big bat" that had perched on the window sill. ${ }^{6}$ Also, when Dracula makes his fifth metamorphosis to vapor after blood-raping Mina, a bat is seen to rise from Renfield's window. Following this, as the six pursue Dracula to

1. Bram Stoker, Dracula (New York: Grosset and Dunlap, 1897). Retrieved from https://bit.ly/2t3EMpw.

2. Stoker, Dracula, 8.89-90; 9.103; 12.148-49.

3. Ibid. 141. Part of the Pampas region referred to by Morris is within the range of the Desmodus rotundus, the real vampire bat, and therefore would be associated with bat attacks. But as Morris makes clear, the vampire bat in question is the large mythic one, which has no presence there. I therefore have no idea why Stoker might have chosen this area; he probably found reference to bat attacks in a travelogue. The large bat, by the way, was placed there in Thomas Carlyle's "Dr. Francia" and Oliver Wendell Holmes' "Farewell to Agassiz" [Thomas Carlyle, "Dr. Francia," The Foreign Quarterly Review 31 (July 1843), 564; Oliver Wendell Holmes, "Farewell to Agassiz," The Atlantic Monthly-A Magazine of Literature, Science, Art, and Politics 16, no. 97 (November 1865), 584].

4. Stoker, Dracula, 14.179 .

5. Ibid., 15.182.

6. Ibid., 18.224-25. 
his eventual demise, the fact that he can turn into a bat regularly enters into their calculations. ${ }^{7}$

Thus Stoker's is a large bat which drinks human blood, hovers and travels with purpose, surveils, sedates, mesmerizes, and feeds with an intention to kill. It is not called a vampire bat-just a vampire.

\section{The Mythic Vampire Bat in the $19^{\text {th }}$ Century}

Since at least the 1970s, Stoker's bat has posed a problem for experts because the true vampire is not big. When we refer to the vampire bat, we almost always mean the common one (Desmodus rotundus), the only one, until recently, ${ }^{8}$ of the three, all indigenous to Central and South America, to feed upon humans. It is known as a "microbat:" it has a body about the size of an adult human's thumb, a wingspan of 14-16 inches from tip to tip, and drinks up to one fluid ounce of blood in a feeding. Its saliva contains an anticoagulant called, tongue in check, "draculin," which causes the wound to continue to bleed after feeding. ${ }^{9}$ So how do scholars deal with the discrepancy between Stoker's bat and the real vampire bat?

Elizabeth Miller, one of a few who has shown real interest in the relationship of the vampire monster and the bat, has argued that "Stoker obviously did not know (or chose to ignore) the fact that the vampire bat is quite small," and thus could not do the damage attributed to it in the book. However, by making it a transformation of a vampire, he created one "quite capable of attacking and draining humans."10

7. Ibid., 25.312; 26.322, 328. Had the Icelandic version been the one originally released in England, Dracula would hardly be associated with bats [Bram Stoker and Valdimar Ásmundsson, Powers of Darkness; The Lost Version of Dracula, trans. Hans Corneel de Roos (New York: Overlook Duckworth, 2017)].

8. Fernanda Ito, Enrico Bernard, and Richard A. Torres, "What is for Dinner? First Report of Human Blood in the Diet of the Hairy-Legged Vampire Bat Diphylla ecaudata," Acta Chiropterologica 18, no. 2 (December 2016).

9. Arthur M. Greenhall, Gerhard Joermann, and Uwe Schmidt, "Desmodus rotundus," Mammalian Species no. 202 (December 1983), 1-6; Jacqueline J. Belwood and Patricia A. Morton, "The truth about the bats people love to hate is even more fascinating than the myths...," BATS Magazine 9, no. 1 (Spring 1991); Bill Schutt, "The Curious, Bloody Lives of Vampire Bats," Natural History Magazine 117, no. 9 (November 2008). Retrieved from https://bit.ly/2KuGues.

10. Elizabeth Miller, "Bats, Vampires \& Dracula," The Night Flyer: News for the Friends of Florida's Bats 3, no. 4 (Fall 1998); Miller, Dracula: Sense and Nonsense (Essex: Desert Island Books, 2000), 34; Miller, A Dracula Handbook (Xlibris, 2005), 46; Miller, "Coitus Interruptus: Sex, Bram Stoker, and Dracula," Romanticism on the Net 44 (November 2006a), 15; Miller, 
Miller is likely the first to face the issue directly. Leonard Wolf in 1975 simply dismissed Stoker's vampire bat and educated the reader on the small one instead. ${ }^{11}$ Matthew Bunson, over fifteen years later, did much the same thing, noting that Europeans named the microbat (not a large one) "vampire" because they were horrified it survived on blood. ${ }^{12}$ Christopher Frayling deviated little from this. ${ }^{13}$

More recently Christopher David was able to annotate a scholar's edition of Dracula without a single comment on the bat. ${ }^{14} \mathrm{~J}$. Gordon Melton, on the other hand, recognized an early tradition concerning vampire bats that goes back to the $16^{\text {th }}$ century but treated it, like Bunson, as if it had always designated small ones. ${ }^{15}$ David Skal likewise noted that bats have a rich place in folklore but then turned to the vampire microbat for the rest of his observations. ${ }^{16}$ Felix Oinas riffed a little on the same. ${ }^{17}$

Basil Copper diverted from his description of the small bat with a single sentence drawing attention to the fact that "vampire" was first attached to a large bat. ${ }^{18}$ Jan Perkovski included in his anthology Ditmars and Greenhall's significant study on the vampire bat, which introduced the history of the large mythic vampire bat, but attached no importance to it in his enthusiasm for the microbat. ${ }^{19}$

So what has interested these professionals is setting the record straight. The true vampire bat is small, therefore Stoker was either in error with his bat or was taking literary license. If the latter, then experts might ignore it or conjecture a reason. Miller, as we saw, holds that the size is important mainly

"Getting to Know the Un-Dead: Bram Stoker, Vampires and Dracula," in Vampires, Myths and Metaphors of Enduring Evil, ed. Peter Day (New York: Rodopi Press, 2006b), 105.

11. Bram Stoker and Leonard Wolf, The Annotated Dracula (New York: Ballentine Books, 1975), 141.

12. Matthew Bunson, The Vampire Encyclopedia (New York: Crown Trade Paperbacks, 1993), 266.

13. Christopher Frayling, Vampyres: Lord Byron to Count Dracula (London: Faber and Faber, 1991), 36.

14. Bram Stoker and Christopher David, Dracula: Scholar's Edition (Self-published, Google Play, 2015).

15. Gordon J. Melton, The Vampire Book: The Encyclopedia of the Undead (Michigan: Visible Ink Press, 2011), 50-51.

16. David J. Skal, Vampires: Encounters with the Undead (New York: Black Dog \& Leventhal, 2001), 402.

17. Felix Oinas, "East European Vampires," in The Vampire: A Casebook, ed. Alan Dundes (Madison: University of Wisconsin Press, 1998), 49.

18. Basil Copper, The Vampire in Legend and Fact (New York: Citadel Press Book, 1973), 48.

19. Jan Perkovski, Vampires of the Slavs (Cambridge, Mass: Slavika Publishers, Inc., 1976), 19-21. 
to explain the extent of blood loss. Clive Leatherdale guesses that Dracula must adhere to a "crude law of constant physical mass," so if he turns into a bat it must be a big one, whereas if he were to become an elephant, it would have to be a small one. ${ }^{20}$

There has been, therefore, virtually no interest in locating an antecedent for Stoker's large bat. Miller is the exception, but the best she has been able to do is locate a single source as a possibility. ${ }^{21}$ She writes that since Stoker referred to Sarah Lee's book entitled Anecdotes of Habits and Instincts of Birds ${ }^{22}$ in his notes for Dracula, perhaps he also read her companion volume, Anecdotes of the Habits and Instincts of Animals. ${ }^{23}$ There Lee speaks of a bat of "monstrous size." But in point of fact, all of Lee's comments are derivative from sources Stoker could easily have encountered elsewhere, as we shall see directly.

Therefore scholars, who have been so determined to reconstruct the development of the vampire myth in the West when it pertains to the monster, have given little attention to the other vampire, to the slow unfolding of the myth of the monstrous bat. Yet the story is equally as interesting and rewarding. ${ }^{24}$

For help, we can turn to the aforementioned 1935 study on the bat by Ditmars and Greenhall. They argued that when Cortez's followers returned "with tales of blood-sucking bats, founded on acquired knowledge of an actual blood-drinking creature," superstitions soon arose of such bats being in the Old World "where no sanguivorous bats have ever occurred." Early naturalists, then, working from legends and deductions from dead specimens rather than by observation, thought the "ugliest and largest bats ... to be the vampire." 25

Early reports from South and Central America were no doubt a complex intermixture of experience, exaggeration, indigenous folklore and art, and sheer imagination, shaped by expectations drawn from Christianity, classical

20. Bram Stoker and Clive Leatherdale, Dracula Unearthed (Westcliff-on-Sea: Desert Island Books, 1988), 158.

21. Miller, Dracula: Sense and Nonsense, 34-35; Miller, "Coitus Interruptus:, 15.

22. Sarah Lee, Anecdotes of the Habits and Instincts of Birds, Reptiles, and Fishes (London: Grant \& Griffith, 1853).

23. Lee, Anecdotes of the Habits and Instincts of Animals (London: Griffith, Faran, Okeden, \& Welch, 1852), 28-30.

24. David E. Brown, Vampiro: The Vampire Bat in Fact and Fantasy (Silver City: HighLonesome Books, 1994).

25. Raymond Lee Ditmars and Arthur M. Greenhall, "The vampire bat; a presentation of undescribed habits and review of its history," Zoologia: Scientific Contributions of the New York Zoological Society 19, no. 2 (April 1935), 70-71. 
mythology, and bestiaries. ${ }^{26}$ Already in 1511, before Cortés sailed to the mainland, Peter Martyr d'Anghiera wrote "in many places bats as large as pigeons flew about the Spaniards as soon as twilight fell, biting them so cruelly that men, rendered desperate, were obliged to give way before them as though they had been harpies." 27 In 1516 he added that "[d]uring the night the men were tortured by bats, which bit them; and if one of these animals bit a man while he was asleep, he lost his blood, and was in danger of losing his life. It is even claimed that some people did die on account of these wounds."14 Ulisse Aldrovandi in 1599 noted that in the hot regions of the world, like India, bats were reported to be savage. They are the size of doves and "attack the faces of people, by striking and wounding in such a way that they sometimes mutilate noses or ears or other parts." 28 Accounts have even surfaced, he says, of people being beaten down by their wings.

Joseph Gumilla described a different function for their large wings in 1731: "if by misfortune a vein is opened, which happens not infrequently, [victims] slip from dream to death, so subtle is the penetration of their teeth, while their wings softly beat the air to cool and lull the sleeper, whose life, they intend to take." 29 In 1745, Charles Marie de la Condamine described the bat as being "monstrous in size," a phrase used repeatedly thereafter; ${ }^{30}$ it was first translated into English as "of a monstrous Bignes." 31 Then in 1758 Carl

26. Elizabeth P. Benson, "Bats in South American Folklore and Ancient Art," BATS Magazine 9, no. 1 (Spring 1991); Benson, "Bats in South American Folklore and Ancient Art," Andean Past 1 (1987), 165-190.

27. Pietro Martire d'Anghiera, De Orbe Novo: The Eight Decades of Peter Martyr D'Anghera, 2 vols. trans. Francis Augustus MacNutt (New York: The Knickerbocker Press, 1963), 1: 179.

28. Ulisse Aldrovandi, Ornithologiae, hoc est de avibus historiae libri XII (Ornithologiae, this is about birds history books 12) (Bonogna: A Sienese Franciscan, 1599), 12: 579.

29. Joseph Gumilla, El Orinoco ilustrado, y defendido: historia natural, civil, y geográfica de este gran río y de sus caudalosas vertientes (The Orinoco illustrated, and defended: natural, civil, and geographical history of this great river and its mighty slopes) (Madrid: Manuel Fernandez, 1745), 406. Leslie Klinger, in a bizarre pseudo-scientific move, adapts this myth of the wings for his readers. "Scientists are quite interested in the bat's saliva, which numbs the victim's skin and lulls the victim to sleep while preventing the blood from clotting" [Bram Stoker and Leslie S. Klinger, The New Annotated Dracula (New York: W. W. Norton \& Co., 2008), 232].

30. Charles Marie de la Condamine, Relation abrégée d'un voyage fait dans l'interieur de l'Amérique méridionale (Abbreviated relationship of a trip made in the interior of South America) (Paris: Veuve Pessot, 1745), 171.

31. George Edwards, A Natural History of Birds (London: College of Physicians, 1751), 201. 
Linnaeus, in a fateful move, named the Malayan flying fox, a megabat with a wingspan of nearly five feet, vampyrus. ${ }^{32}$

In English, Thomas Pennant mentioned in 1771 the vampire, which was enormous, fanning the air with its wings to create "a still sounder sleep" and "insinuat[ing] its aculeated tongue into a vein without being perceived, and then suck[ing] the blood till it is satiated."33 John Gabriel Stedman in 1796 gave one of the most quoted descriptions in the $19^{\text {th }}$ century. Therein he spoke of being bitten by a "vampire or spectre of Guiana." He described it as "a bat of monstrous size, that sucks the blood from men and cattle when they are fast asleep, even sometimes till they die." It does this by feeding to satiation, disgorging, and sucking again until it can hardly fly; it has a wingspan as wide as three feet. ${ }^{34}$ The naturalist William Wood in 1807 extended the span to four feet. ${ }^{35}$ In 1825 Charles Waterton wrote a book that was reprinted throughout the century, describing several visits by these large "nocturnal surgeons." 36 Always ready for a nice turn of phrase, he called them elsewhere, "sanguinary imps of night." 37

These reports were confirmed in 1847 by Richard Schomburgk ${ }^{38}$ and in 1853 by Alfred Russel Wallace. ${ }^{39}$ Wallace identified the second largest bat in

32. Carl Linnaeus, Systema Naturae, 10th ed. (Stockholm: Salvius, 1758), 1.31. MacNally and Floresçu advance the ludicrous claim that Cortés himself named them vampire bats [Raymond MacNally and Radu Floresçu, "Vampirism: Old World Folklore," in The Vampire in Slavic Cultures, ed. Thomas J. Garza (San Diego: University Readers, 1994/2009), 47.

33. Thomas Pennant, Synopsis of Quadrupeds (Chester: J. Monk, 1771), 361-362; on the tongue [Georges-Louis Leclerc, Comte de Buffon, Histoire Naturelle, générale et particulière, avec la description du Cabinet du Roi (Natural History, general and particular, with the description of the Cabinet of the King) 10, 1763, 64-65, 78].

34. John Stedman, Narrative, of a Five Years' Expedition, Against the Revolted Negroes of Surinam, in Guiana, on the Wild Coast of South America; from the Year 1772, to 1777: Elucidating the History of that Country, and Describing Its Productions, Viz. Quadrupedes, Birds, Fishes, Reptiles, Trees, Shrubs, Fruits, \& Roots; with an Account of the Indians of Guiana, E Negroes of Guinea 2 (London: J. Johnson and J. Edwards, 1796), 142-144.

35. William Wood, Zoography, Or, The Beauties of Nature Displayed: In Select Descriptions from the Animal, and Vegetable, with Additions from the Mineral Kingdom Systematically Arranged (London: Dadell and Davies, 1807), 347-349.

36. Charles Waterton, Wanderings in South America, in the North West of the United States, and the Antilles, in the Years 1812, 1816, 1820, and 1824 (London: J. Mawman, 1825), $11,153,174-179,287-289$.

37. Waterton, Essays on natural history, chiefly ornithology (London: Longman, Orme, Brown, Green and Longmans, 1838), 70-72.

38. Richard Schomburgk, Travels in British Guiana During the Years 1840-1844 (Leipzig: J. J. Weber, 1847), 225-226. 
Latin America, the Phyllostomus hastatus, as the one in question, rather than the largest one. He appended an interesting theory from his brother about how the bat creates the incision: it places a canine tooth on the victim and then drills it in slowly by flying around in circles, all the while fanning the victim into deeper sleep.

"Vampire" entered taxonomy with Linnaeus and it leaves a legacy to this day. The most prodigious bat in the Americas is named the Vampyrum spectrum. Linnaeus' vampire is known today as the Pteropyus vampyrus. There are the genera and subgenera Vampyressa (1843), Vampyrops (1865), and Vampyrodes (1889). Many others became popularly known as vampires, although their scientific names today do not reflect it; they are now called "false vampire bats."40 Johann von Spix famously designated the Glossophaga soricina as "a blood-sucker most cruel" (Sanguisuga crudelissima); it was sometimes known as the "longtongued vampire."41

In the 1840s the descriptions of the bat began to be tempered by Darwin's direct observation of the Desmodus rotundus feeding on blood, the first sighting to be taken seriously. ${ }^{42}$ Before him, by the way, in 1801, Felix de Azara described this blood-sucking bat with considerable care, but was immediately ignored..$^{43}$ By Stoker's time, sources might deal with the mythic one by itself or some compromise between it and the proper one. ${ }^{44} \mathrm{~A}$ few even dealt with the

39. Alfred Russel Wallace, A Narrative of Travels on the Amazon and Rio Negro: With an Account of the Native Tribes, and Observations on the Climate, Geology, and Natural History of the Amazon Valley (London: Reeve \& Co., 1853), 449.

40. Barbara French, "False Vampires and Other Carnivores: A glimpse at this select group of bats reveals efficient predators with a surprisingly gentle side ...," BATS Magazine 15, no. 2 (Summer 1997).

41. Johann von Spix, Simiarum et Vespertilionum Brasiliensium species novae ou Histoire Naturelle des espècies nouvelles de singes et de chauves-souris observées et recueillies pendant le voyage dans l'interieur du Brésil exécuté par ordre de S M Le Roi de Bavière dans les années 1817, 1818, 1819, 1820 (Simiarum and Vespertilionum Brasiliensium species novae or Natural History of the new species of monkeys and bats observed and collected during the journey in the interior of Brazil executed by order of S M The King of Bavaria in the years 1817, 1818, 1819, 1820) (Munich: Typis Francisci Seraphi Hybschmanni, 1823), 66-67.

42. Charles Darwin, Narrative of the surveying voyages of His Majesty's Ships Adventure and Beagle between the years 1826 and 1836, describing their examination of the southern shores of South America, and the Beagle's circumnavigation of the globe. Journal and remarks. 1832-1836 (London: Henry Colburn, 1839), 3: 24-25.

43. Felix de Azara, Essais sur l'histoire naturelle des quadrupèdes de la province du Paraguay (Essays on the natural history of quadrupeds in the province of Paraguay) (Paris: Charles Pogens, 1801), 2: 273.

44. For an extensive compromise, see Lydekker [Richard Lydekker, ed., The Royal Natural History 1 (London: Frederick Warne \& Company, 1893-94), 1: 299-306]. 
true vampire with no reference to the large one. ${ }^{45}$ In popular culture, it was strictly the legendary one that was used.

So Stoker had readily available to him a vampire that was very large, had predatorial instincts, and sucked blood to such a degree that it could take a life. It used its wings to sedate hypnotically, both while hovering and while feeding. Stoker did not invent it, by making it a human-like vampire monster in a transformed state, but utilized a bat that already existed, albeit in people's imagination, and affixing it to the monster. It is correct, then, that he may have ignored the Desmodus rotundus, but is not so in insinuating the mythic one to be hard to account for. And the language was most often of the vampire rather than the vampire bat.

\section{The Conflation of Monster and Bat}

Because the $19^{\text {th }}$ century uses "vampire" to designate both the bat and the monster, we have to be careful when reading literature from the period. In fact, the latter half of the century seems to represent a shift away from a supernatural monster to a more normalized vampire, and the bat is part of this. For this we shall look at an article by Andrew Boylan that lists works he believes lead up to Stoker to see if a pattern emerges. ${ }^{46} \mathrm{He}$ is a respected enthusiast and the only one I know to investigate the issue at any length. All the references are intended to designate a blurring of boundaries between the monster and bat, with the idea that Stoker might have got his idea of metamorphosis from one or more of the references.

Boylan notes first the 1888 entry in the Encyclopedia Britannica and an 1896 article from the New York World dealing with "vampirism" in New England. In each case both the monster and the bat are brought together in a single article. He goes on to reference Richard Burton's 1870 story Vikram and the Vampire where a creature, identified as a vampire, hangs from a bough, "like a flying fox;" a cartoon in Punch (1885) where the Irish National League is identified as the Irish "Vampire," and pictured as a bat, "replete with human face;" Goya's print Las Resultas (1810-20) which shows a bat "with a humanoid face suckling on the chest of a corpse;" Dumas' 1851 play where Ruthven, the vampire, is revived from death, spreads his "great wings and flies off;" "A. Y."'s 1829 story, "Pepopukin in Corsica," of an "invented vampire" who sings of flying over the alps; Bruxas in William Kingston's 1863 short story who are ordinary women during the day but become vampires at night and can transform into "gigantic bats;" Baring-Gould's 1884 "Margery of Quether" whose vampire has

45. Alden's Cyclopedia of Natural History 2 (New York: John B. Alden, 1893).

46. Andrew Boylan, "Stoker and the Bat," Vamped (April 1, 2014); see also Boylan, Media Vampire: A Study of Vampires in Fictional Media, Lulu.com. (2012), 183-184. 
hands and arms "shrivelled and like those of a bat;" Christian iconography like the painting of St. Michael by Carlo Crivelli (c. 1476) where the devil (which translates to "Dracula") has bat wings; and the 1896 short film, Le Manoir du Diable, by Georges Méliès where Mephistopheles turns from a large bat to a human.

Elizabeth Miller adds two others: first a "bat-like vampire appears ... as a cover illustration in the novel VARNEY THE VAMPIRE, which appeared fifty years before DRACULA." 47 Then, "The Mysterious Stranger, as Count Klatka keeps company with the bat and the owl."48 Boylan concludes his paper, "[W]hat we have seen is a rich pre-Stoker connection between bats and vampires ... Certainly Stoker was not the first to suggest that a vampire could transform into a bat. The best that can be said is that he popularised the connection."

I will look at these chronologically, changing any problems with dating.

First is Crivelli's painting. Christianity picked up the notion of wings on its devils and angels early on. For instance, the early Latin father, Tertullian, wrote in the late second century, "Every spirit is possessed of wings. This is a common property of both angels and demons." 49 The first differentiation of them into feathered and bat-like, albeit meant strictly metaphorically, is probably by the Greek Father, Basil of Caesarea, in the mid-fourth century: "The bat is indeed winged, yet it is not furnished with feathers, but flies through the air by means of a fleshy membrane. Such are demons as well."50

It does not seem to have occurred in earnest until the late high Middle Ages. The frescoes by Giotto, "The Exorcism of the Demons" [Scene 10] and "The Confession of the Woman of Benevento" [Scene 27] dated between 1295 and 1299 were quickly followed by Duccio Di Buoninsegna's "The Temptation of Christ on the Mountain" and "Descent to Hell" (1308-11). Dante around 1314 insisted that the devil's wings were not feathered, "but were in form and texture like a bat's."51 So Crivelli is just a later instance of this. Boylan is right

47. Miller, "Bats, Vampires \& Dracula." Miller writes, "The first literary connection with vampires-I am not aware of any connection in the folklore-may be the cover illustration of an early edition of Varney the Vampire" (Miller, Dracula: Sense and Nonsense, 34). There in fact is a slight connection in folklore. Paul Barber says, "In Romania it is reported that by flying over a corpse a bat can create a vampire" [Paul Barber, Vampires, Burial, and Death: Folklore and Reality (New Haven: Yale University Press, 1988), 33].

48. Miller, Dracula: Sense and Nonsense, 34.

49. Tertullian, Apologeticus. Ante-Nicene Christian Library 11. Alexander Roberts and James Donaldson (Edinburgh: T. \& T. Clark, 1869), 68.

50. Saint Basil (Bishop of Caesarea), Commentary on the Prophet Isaiah, Texts and Studies in the History of Theology 7, trans. Nicolai A. Lipatov, ed. Kinzig Wolfram and Vinzent Wolfram (Cambridge: Edition Cicero, 2001), 110.

51. Dante, Inferno, trans. Carlyle John Aitken (London: J. M. Dent \& Co., 1904), 385; cf. Luther Link, The Devil: A Mask Without a Face (London: Reaktion Books, 2004), 67-68. 
insofar as it is a conflation of a monster and a bat, but it is a stretch to see it leading up to Dracula. ${ }^{2}$

Goya's print adds nothing: it is merely his use of the mythic vampire bat sucking the life out of a victim while resting on his stomach as a symbol for the horror of war to a nation. He is probably working with the famous picture Nightmare by Henry Fuseli where the mare of folk stories sits upon the chest of a sleeping beauty giving her nightmares (1781). The $19^{\text {th }}$-century vampire bat in literature, whether or not dependent upon Goya, is henceforth likely to be sitting on the ribs or stomach sucking blood from the chest or throat. ${ }^{53}$

A.Y.'s 1826 story is significant. ${ }^{54}$ The vampire is a prank, but taken on its own terms, the monster is said to rise from its grave clothes and fly over the alps, dripping from his "blood-swol'n body." Yet it does not tie together the monster either with the bat or with bat wings, but only with wings and flying. Heaven is promised to him and he attacks only sinners, so there is no reason his wings not be feathered.

"The Mysterious Stranger" was published in German in 1844 and a translation into English printed in $1854 . .^{55}$ The passage in question-keeping company with the bat and the owl-simply means he is asleep during the day. In the German it is ich mit Kauz und Uhu niste, "I nest with the screech and eagle owls." 56

52. In fact I think it is the opposite, but this is pure conjecture. In prospect I believe one reason it took some time before the two vampires were brought together intimately was because the bat was already taken by Christianity's evilest figure. On the other hand, in retrospect, when Stoker adopted the name for his monster, he may have made some interesting connections between the satanic wings, the vampire monster, and the vampire bat. On the other hand, the vampire bat and Satan were linked together closely by 1866 [Thomas Carlisle, "Natural History: Bats," The Juvenile Instructor and Companion 17-5 (1866), 118].

53. Goya has a much earlier etching that obviously uses vampire bats in the background: "There is Plenty to Suck" (c. 1798). Retrieved from https://bit.ly/2NsWBH1.

54. Arthur Young, "Pepopukin in Corsica," in The Stanley Tales 1, ed. Ambrose Marten (London: W. Morgan, 1826), 53-54.

55. 1860 was given by Montague Summers as the date of the English translation in Victorian Ghost Stories (1934) and it was used in English sources thereafter. Recent critical studies place it in 1854. The research of Douglas A. Anderson and Thomas Honegger resulted in locating the original German and so the record was finally set straight by Mike Ashley, who credits them [Mike Ashley, Vampires: Classic Tales (Mineola: Dover Publications, Inc., 2011), 33].

56. Carl Adolf von Wachsmann, "Der Fremde," Erzälungen und Novellen 3: 7 (Leipzig: Carl Jocke von Wachsmann 1844), 167, Retrieved from https://bit.ly/2JyrIPe; Anonymous, "The Mysterious Stranger," Chambers's repository of instructive and amusing tracts 4 (Edinburgh: William and Robert Chambers, Tract 62, 1854), 15, Retrieved from https://bit.ly/2zZbZcC. 
Next is Dumas and this does appear to be a genuine conflation of the two vampires. ${ }^{57} \mathrm{He}$ has two supernatural vampire characters that are set in conflict with each other. He calls the female one "a ghoul" and links her with Arabs. ${ }^{58}$ Ghouls are said to be coquettes, choosing handsome young men and then lying in wait for them. "They watch for the passing of their prey, lull him to sleep with the movement of their vast wings and when he is asleep in a mortal bliss, they aspirate his blood and his life." 59 There is no doubt about her being a preternatural monster, with vampire bat wings which sedate. Lord Ruthven, the other vampire, dead among the mountain rocks, is revived by moonlight. "Lord Ruthwen first sits up-then rises completely, ... deploys great wings and flies off." 60 Dumas uses the same construction he does for the ghoul: grandes ailes - vast wings. Both are surely hybrids of the vampire monster and bat. ${ }^{61}$

Miller's reference to the illustration in Varney the Vampire also appears to be a conflation of the two. The story was originally printed between 1845 and 1847 as a "penny dreadful." It was published in book form in 1847. What Miller is referring to is the cover of the 1853 edition. ${ }^{62}$ A skeletonized Varney spreads his cloak to form bat wings and hovers over a sleeping beauty. He is surrounded by four demons complete with bat wings watching eagerly. So the illustration does seem to bring together the vampire monster and the bat. But

57. Alexandre Dumas, The Return of Lord Ruthven the Vampire, trans. Frank J. Morlock (Tarzana: Hollywood Comics, 2004).

58. The "ghoul" first appeared in "The Story of Sidi Nouman" in Antoine Galland's translation/ adaptation of the Arabian Tales [Les Mille et Une Nuits, 10, 1712; see the reprint, 1785, 35-56, retrieved from https://bit.ly/2zSyTlM]. It is most likely a creation of Galland himself. The ghoul was later "vampirized" by Collin de Plancy (1820, 104-16), where de Plancy doubtless fabricated an "Arabic" story based on "Sidi Nouman." Dumas is simply pulling from this tradition. For an important perspective on the ghoul, see Ahmed K. Al-Rawi [Ahmed K. Al-Rawi, "The Arabic Ghoul and its Western Transformation," Folklore 120 (December 2009)].

59. Dumas, The Return of Lord Ruthven the Vampire, Act 2, scene 2.

60. Dumas, The Return of Lord Ruthven the Vampire, Act 3, scene 3.

61. A vampire of a similar sort is also described in the anonymously written adolescent novel, The Vampire, or Detective Brand's Greatest Case 1885, 8. It uses "bird" for "bat" throughout the story. "Tain't a bird, ... but a sort of a devil w'ot comes in the shape of a big bird; it's got the figger of a man, but the wings of a bird, a kinder hitched onto a man's arm, and the only thing it can live on is human blood." So too the famous picture by Albert-Joseph Penot La chauve-souris circa 1890. See Rossbach [Susanne Rossback, Des Dandys Wort als Waffe: Dandyismus, narrative Vertextungsstrategien und Geschlechterdifferenz im Werk Jules Barbey d'Aurevillys (The dandy's word as a weapon: Dandyism, narrative strategies of articulation and gender difference in the work of Jules Barbey d'Aurevilly) (Tübingen: Max Niemeyer Verlag, 2002), 138].

62. Edward Pettit, Varney the Vampire by James Malcolm Rymer. Retrieved from https://bit.ly/2KBgk9Y. 
because of the emphasis on the bat by the appearance of the four demons and of him hovering over her like a bat, the illustration is more about it than the monster. A similar picture, by the way, is painted by Charles Dickens in Bleak House (1852-3): Mr. Krook finds his tenant dead on the bed and calls for help, "with his lean hands spread out above the body like a vampire's wings."63

We turn to Burton's very free translation of The Baital-Pachisi or Vetala Panchavimshati entitled Vikram and the Vampire. ${ }^{64}$ It ends up being largely irrelevant to our study. "Vampire" is a misleading translation for baital or vetala, a Hindu impish and devious trickster spirit that can inhabit corpses in charnel grounds. "Vampire" refers to the spirit, whether incarnate or disembodied; it corresponds to the way the word became used by Spiritualism and Theosophy ${ }^{65}$ Insofar as it inhabits a dead human body, there is a parallel with the monster. Here it animates an altered body that looks like a flying fox, i.e., a vampire bat. So "vampire" refers to neither the monster nor the bat as such, but to the spirit behind them both.

Margery of Quether, over two hundred years before the story of the same name, used to sit in church and pray for everlasting life and her Christian God granted it. ${ }^{66}$ She now lives like a bat in the belfry of the church, shrunk to the size of an infant in mummified flesh. This is how George Rosedhu encounters her. She drops from the bell rope, scrambles on the ground "much as [he has] seen a bat scramble," has hands and arms shrivelled "like those of a bat," and when his heart goes out to her and he decides he will protect her in his home, she clings to his chest clutching him with her "bat like hands and claws" and sinks her one remaining tooth deep into his flesh. She is a bat situated on his breast and feeding. Thus begins a strange relationship where George suckles her back to youth as he himself slips into decrepitude and old age. Her "vampirism" (the word "vampire" never appears) is imaged $100 \%$ as that of a bat; her transformation from being "bat like" to being "normal" is slow and in stages as was her change from human to being bat like beforehand. The figure of a bat is superimposed on the human at one stage of her life; there is no conflation of a monster and bat, for there is no monster.

63. Charles Dickens, Bleak House (London: Bradbury \& Evans, 1853), 97.

64. Richard F. Burton, "Vikram and the Vampire; or, Tales of Indian Devilry," Fraser's Magazine for Town and Country 77 (April 1868); for a contemporary proper translation see Platts [John Tompson Platts, The Baital Pachchisi, or, The Twenty-five Tales of a Sprite (London: Wm. H. Allen, 1871)].

65. Burton, "Vikram and the Vampire; or, Tales of Indian Devilry," 409.

66. Sabine Baring-Gould, "Margery of Quether," The Cornhill Magazine (April 1884). Baring-Gould is Christianizing classical myths which counsel human beings to avoid hubris and accept their mortality. Those who wish to be like the eternal gods live to regret it. The Sibyl of Cumae shrivels up with her increasing years like a cicada-so does Tithonus, Eos's favorite; both, in their withered condition, plead for their ever-elusive death. 
The 1888 entry on "vampire" in the Encyclopaedia Britannica follows. ${ }^{67}$ The two vampires are put together because they share the same name. The bat gets more space because it is the object of greater interest. Instead of conflation, it displays the bat's primacy. In fact, the author writes that the word vampire "originally applied in eastern Europe to blood sucking ghosts, but in modern usage [is] transferred to one or more species of blood sucking bats inhabiting South America." 68 In other words, usage for the monster is archaic; for the bat it is current. So too the 1896 article from the New York World; although it is only about the monster, the author devotes the final paragraphs to the bat, since it is "more recent" and is "founded on fact" rather than superstition. ${ }^{69}$

The illustration in Punch is misunderstood if one holds "The Irish Vampire" as meaning anything more than the bat. A huge bat, with the National League written on its wings, hovers over the sleeping body of Ireland (or "Hibernia") ready to take her life. ${ }^{70}$ Punch was a humor weekly which saw any nationalist movement, like the Irish League, to be destructive of the British Empire. That is why superimposed on the bat's face is that of Charles Stewart Parnell, an "infamous" supporter of home rule and organizer of the National League. ${ }^{71}$ Parnell is a vampire to the staff at Punch only in the sense of the bat.

Images like this were prevalent at the time. A particularly provocative one appeared in the January 28, 1893 issue of the Worker out of Brisbane, Australia, with the caption "Queensland and the Vampire." A vampire bat with Q. N. Bank on its wings is on the belly of a prostrate topless woman sucking blood and milk from her breast. On the head is the face of the general manager of the Queensland National Bank, Edward Robert Drury, who is extracting the assets of Queensland for the sake of outside investors. In the terms of the time, both are "human vampires."72

67. G. E. Dobson, "Vampire," Encyclopaedia Brittanica 24 (New York, 1888), 52.

68. Cf. "They Burned the Vampire," Healdsburg Tribune, Enterprise and Scimitar 14 (June 22, 1893). Retrieved from https://bit.ly/21PN3ua.

69. Bram Stoker, Richard Eighteen-Bisang, and Elizabeth Miller, Bram Stoker's Notes for Dracula: A Facsimile Edition (Jefferson, North Carolina: McFarland \& Company, 2008), 186-193.

70. John Tenniel, The Irish Vampire, Punch, or The London Charivari 39 (October 17, 1885), 198-199. It is preceded by a poem with the same name, wherein the luckless Erin (Ireland), beset by problems, has attracted yet new ones. She is counselled to wake up and put up her guard lest they take her life. She is facing the preditorial National League which arose in her midst from her lack of vigilance.

71. Dalby comments how the face reminds him of Stoker's [Richard Dalby, Dracula's Brood (New York: Dorset Press, 1987), 11-12].

72. A "human vampire" is used during the final decades of the 19th century to denote someone acting like a vampire bat. A good example is Napier [Charles Ottley Groom Napier, The Book of Nature and the Book of Man (London: John Camden Hotten, 1870), 263-264]. Cf. the "Death Watch" dinner put on by the Order of the Vampires, 
Along the same lines, at the beginning of Mary Elizabeth Braddon's 1896 "Good Lady Ducayne," a story in which a wealthy elderly woman hires lower middle class women in order secretly to have their blood transfused into her to extend her life at the threat of their own, is an illustration of an old woman in a fur coat with a huge imposing bat hovering behind her. She is acting like a vampire (bat)..$^{73}$ The first instance of this kind of illustration of which I am aware features a frightful human face placed on the body of a vampire bat with a handsome mask dangling down on his chest. As the description that accompanies it makes clear, the vampire is to represent the sadistic hypocrite who seems a friend but secretly slanders behind one's back. It is entitled "Vampire," and refers solely to the bat. ${ }^{74}$

Perhaps most striking comes from a review of Dion Boucicault's "The Phantom," an 1852 adaptation of Charles Nodier's 1820 play, "The Vampire." The notation is from a revival of it and appears in the January 20, 1875 New York Times by M. E. W. Sherwood. "Then somewhere along here, I think in a summer season, comes a vision of Boucicault playing the Vampire, a dreadful and weird thing, played with immortal genius. That great playwright would not have died unknown had he never done anything but flap his bat-like arms in that dream-disturbing piece."75

\section{The Metamorphosis into a Bat}

Nina Auerbach and David Skal wrote in 1997 that "the now-inevitable association of vampires with the bat" began with Dracula. ${ }^{76} \mathrm{~J}$. Gordon Melton and Heide Crawford aver much the same. ${ }^{77}$ In 1998, Elizabeth Miller declared more strongly "Stoker's major contribution to the association of vampires with

i.e., vampire bats, October 2, 1892 in New York city. The program had a large vampire bat flying over a grave with the words "Homo Desmodus" streaming across its body. Homo Desmodus is translated in this context "Human Vampire." Anonymous, Death Watch (New-York Historical Society: October 28, 2011).

73. Mary Elizabeth Braddon, "Good Lady Ducayne," The Strand Magazine: An Illustrated Monthly 11 (February 1896), 185.

74. Henry L. Stephens, The Comic Natural History of the Human Race (Philadelphia: S. Robinson, 1851), 184-188.

75. M. E. W. Sherwood, Review of Boucicault's "The Phantom," in Actors and Actresses of Great Britain and the United States: From the Days of David Barrick to the Present Time 5, ed. Brander Matthews and Laurence Hutton, 87-88 (New York: Cassell \& Company, 1886/1875).

76. Bram Stoker, Nina Auerbach, and David J. Skal, Dracula: A Norton Critical Edition (London: W. W. Norton \& Co., 1997), 90.

77. Melton, The Vampire Book: The Encyclopedia of the Undead, 52; Heide Crawford, The Origins of the Literary Vampire (Lanham: Rowman \& Littlefield, 2016), 41. 
bats was his introduction of the idea that a vampire could shapeshift into the form of a bat (as well as a wolf and mist)." Anthony Hogg, an accomplished amateur, has asserted "that Stoker invented one of the most popular "folkloric" characteristics associated with vampires: they could change into bats."78 Hogg also holds that finding a list that predates Dracula and includes a bat as something into which a vampire (monster) can turn would be "an exciting find."79

First, we must deal with the remaining sources to which Boylan refers. William H. G. Kingston's The Vampire; or, Pedro Pacheco and the Bruxa (1863) is not an early instance of metamorphosis. ${ }^{80}$ Ordinary women by day, bruxas become demon possessed by night and have orgies. The name bruxa means a witch, and witches are already associated with night orgies and demon possession. They can also shapeshift, so it is no surprise that following the orgy they turn into bats, ducks, or owls. As such they lead passers-by on a wild goose chase, leaving them lost, scratched, and humiliated, and finally return home and with a "vampirish hunger," seize their children, fan them with their huge black wings, bite them, and "suck the life-blood from their veins." The vampire in the title refers only to the bat. There is no vampire monster, only a witch. Stoker read a highly abbreviated story similar to this, by the way. ${ }^{81}$

Le Manoir du Diable by Georges Méliès (1896) has been called "the first vampire film." 82 It features a monster, Mephistopheles, turning into a bat and vice versa. But Mephisopheles is an imp of the devil created in the sixteenth century along with the first Faust tales and thereafter a surrogate for the devil; he is never a vampire monster. It does demonstrate the interchangeability between a human-like devil and a bat (there is no evidence it is a vampire bat), but bats have been associated with the devil for a long time. Nonetheless transformation is important, even if it does not apply immediately to the vampire. So there are only two on Boylan's and Miller's lists that are germane.

78. Anthony Hogg, "Bats Before Bram," The Vampirologist (April 6, 2014). Retrieved from https://bit.ly/2lMIQas.

79. Hogg, "Bats Where They Don't Belong," Diary of an Amateur Vampirologist (January 25, 2011). Retrieved from https://bit.ly/2tMgK3A.

80. The same story was published in 1846 and 1863, albeit with different names for the lead character. In 1863, however, an introduction was affixed and it is that alone which concerns us.

81. Stoker, Eighteen-Bisang, and Miller, Bram Stoker's Notes for Dracula: A Facsimile Edition, 206-209; Isabella Lucy Bird, The Golden Chersonese and the Way Thither (New York: G. P. Putnam's Sons, 1883), 451-452.

82. Phil Hardy, Tom Milne, and Paul Willemen, ed. Overlook Film Encyclopedia: Horror, (Overlook Press, 1995), 17; Roxana Stuart, Stage Blood: Vampires of the 19th Century Stage (Bowling Green, Ohio: Bowling Green State University Popular Press, 1994), 218. 
There is nothing controversial about the folklore vampire being a shapeshifter. What is of significance, we are told, is the absence of the bat from any such list. In Wendische Sagen, Märchen und abergläubische Gebräuche (1880), however, which refers to the stories and rituals of the Western Slavs, there is a sentence on the issue: Die Vampyre nehmen die Gestalt von Katzen, Fröschen, Kröten, Fliegen, Spinnen oder Fledermäusen an-"Vampires take the form of cats, frogs, toads, flies, spiders, or bats." 83

Another can be found a year earlier in a textbook entitled Simple English Poems (1879). In an explanatory footnote to Robert Browning's "The Pied Piper of Hamlin," which makes a passing reference to "Vampyre bats," we read that they are "huge bats found in the tropics, so called from the superstition about vampyres. A vampyre is supposed to be a dead man who returns in body and soul from the other world, and wanders about the earth doing mischief to the living. He sucks the blood of persons asleep, and these persons become vampyres in turn. He lies as a corpse during the day; but at night, especially at full moon, he wanders about in the form of a dog, bat, \&c, biting sleepers on the back or neck." 84

With regard to literature, there is at least one story that features a vampire monster turning into a vampire bat. ${ }^{85}$ It is entitled "A Vampire" and is by Karl May. ${ }^{86}$ May wrote his Orient Cycle between 1881 and 1888, and it was published in installments in the Catholic weekly, Deutscher Hausschatz in Wort und Bild. The fourth volume of the cycle, In den Schluchten des Balkan, appeared in the 1885-86 issues. It was then revised and published in book form in 1892. This is found in the seventh chapter.

Kara Ben Nemsi is traveling in the Bulgarian Mountains with his companions. They spend the night at the home of a poor Christian man, Kerpitschi. Kara learns that the man and his wife are fasting that night, so he goes outside to eat and notices there the grave of their daughter who recently had died. When he is finished and returning to the house, Kerpitschi stops him to ask whether he believes in ghosts. Kara says he does not, but Kerpitschi

83. Edmund Veckenstedt, Wendische Sagen, Märchen und abergläubische Gebräuche (Wendish legends, fairy tales and superstitious customs) (Graz: Leuschner and Lubensky, 1880), 354.

84. Courthope H. Bowen, ed. "Simple English Poems: English Literature for Junior Classes," in Four Parts (London: C. Kegan Paul and Co., 1879), 42 (part two).

85. The jury is still out on "The Vampire Maid" by Hume Nisbet. In The Vampire Archives, Otto Penzler, writes that "The Vampire Maid" was first published in a magazine in 1890 and then reprinted in book form in 1900. Penzler cannot recall where he found the datum. Mike Ashley, Douglas A. Anderson, James Doig, and I can find no evidence for the claim.

86. Oliver Kotowski, ed. Lasst die Toten ruhen: Deutsche Vampirgeschichten aus dem 19 (Let the dead rest: German vampire stories from the 19th) (Jahrhundert, Stolberg: Atlantis Verlag, 2012), 189-217. 
responds that he knows they exist for their daughter is a vampire; his wife and he fast in order to redeem her.

He is told that their daughter, who was already ill, cared for her fiancé's mother as she was dying of small pox. She returned home after her death frightened-something had happened to her there-and soon became delirious. In this state, she would say that Wlastan's son, her fiancé, must die. When she was near death the priest was gone so she made no confession and received no absolution; because she died of small pox she could not be buried in the cemetery. So presently she becomes a bat, knocks on their door, and then flies over to Wlastan's home and feeds on his son, who has started to waste away. "Now she is a vampire and she is keeping him for herself." The priest has said the only way to stop her is to stake her, but they will not allow it. Thus, Wlastan, who was once a close friend, is now his enemy.

Kara decides to keep watch over the house, even though Kerpitschi tells him he must not, for no one can look at a vampire and live. That is the reason why they have never answered the door. Kara says he will do so anyway for he wants to see a "ghostly leech behind membrane-wings." Kara sees a man come that night and make bat noises and knock on the door; he is eventually caught and confesses. It is Wlastan's servant who has slowly been poisoning Wlastan's son, so that he himself could become heir. Kerpitschi's daughter caught him, but he threatened to kill her parents if she ever told anyone. That is why she spoke as she did.

There is, by the way, another: "The Stone Chamber" by H. B. Marriott Watson. It is often dated 1898 or 1899 , taken from the publication of the book in which it appears, but it was actually printed first in mid-1896. It clearly implies the turning of Priscilla, Lady Marvyn, dead some 150 years, into a bat which is currently feeding on occupants in the stone chamber but it is worked out only in 1898; the 1896 version is too abbreviated..$^{87}$

\section{Final Reflections}

There does seem to have been an almost inevitable collision course between the two vampires - monster and bat-if for no other reason than they shared the same name and tended to have similar traits. That started when soldiers, naturalists, even taxonomists began naming bats with the name of the folklore monster and creating a list of lurid characteristics for them. In this

87. In the US, it appears on page 29 of the June 28, 1896 issue of the New York World. Retrieved from https://www.newspapers.com/newspage/4014154/. Mike Ashley seems have located an earlier appearance on June 11 in Vanity Fair. The 1898 version can be read at https://archive.org/stream/-heartofmirandaot00wat siala\#page/140. 
way, many of the terrifying aspects of the monster were preserved but the "superstitious" elements could be removed-no more revenants, or ritualized desecrations and stakings, or the victims becoming vampire monsters, or theological problems about how such fit into the order of a benevolent, but just God's creation.

In the latter half of the century the monster seems to be in the process of being naturalized. If referred to at all and not the bat, the monster becomes a psychic vampire mesmerizing, a medical one transfusing, a scientist electrically magnetizing, a femme fatale or homme fatal seducing; a killer murdering; a necrophile desecrating, etc. All draw the life force, resources, dignity from their victims. At the same time the unreconstructed monster becomes largely the property of folklorists, early psychologists, and love poets. After Dumas, Lord Ruthven slips increasingly into the shadows of redundancy or parody.

Nonetheless, the monster does still live on at the margins of $19^{\text {th }}$-century literature. Most of the authors of these stories, however, prefer to keep their options open between coincidence, illusion, trickery, and reality, as May does. A world like ours where the monster can operate unapologetically becomes rare. Yet a few masterpieces still arise like J. Sheridan Le Fanu's Carmilla in English; 88 Marie Nizet's Le Capitaine Vampire in French; ${ }^{89}$ and Heinrich Ulrichs' "Manor" in German, ${ }^{90}$ but these, for the most part, were overlooked at the time of their publication.

Dracula should have joined them here at the fringes, but instead it broke out and has become one of the best selling novels to this day. Stoker's use of the contemporary large and menacing bat-to spy, to sedate, to hypnotize, to prey upon, to escape-as one weapon in an arsenal to be wielded by a relentless, foreign, imperial monster bent on conquest in the very heart of the British Empire at the time is quite staggering. In comparison, the previous literary associations of a corpse and a bat are rather anemic.

This is where we must see the significance of the book. It does not lie in its being the first to utilize the bat as something into which the monster can shapeshift. Nor is it the climax of a mainstream movement in its direction. Rather it plays a key role in reasserting the primacy of the monster over the bat that typified the first half of the century. In the latter half, if one used the word "vampire," chances are one meant the bat. Today we mean by it the monster alone and if we refer to the bat, it is merely an adjective.

88. J. Sheridan Le Fanu, "Carmilla," The Dark Blue 2 (December 1871).

89. Marie Nizet, Captain Vampire, trans. Brian Stableford (Tarzana, CA: Black Coat Press, 2007; first published 1879).

90. Heinrich Ulrich, "Manor," in Lasst die Toten ruhen: Deutsche Vampirgeschichten aus dem 19 (Let the dead rest: German vampire stories from the 19th), ed. Oliver Kotowski (Jahrhundert, Stolberg: Atlantis Verlag, 2012). 
Finally, the $20^{\text {th }}$ century saw the victory of the microbat over the macrobat as the true vampire, so when a monster turns into a large bat, it is not technically into a vampire bat anymore. Dracula is the greatest example of an era when that was not the case, when the monstrous bat still reigned as the vampire.

\section{Acknowledgements}

I would like to thank Dr. Bill Hook who worked with Vanderbilt University to obtain and maintain for me the status of a Visiting Scholar; Douglas A. Anderson and Mike Ashley for reading and commenting on the earliest version of this paper; Anderson Gaither for translating Latin texts; Marcia Epelbaum for correcting my Spanish. For Norma Louise Sparrow, Requiescat in pace et in amore.

\section{Bibliography}

Al-Rawi, Ahmed K. "The Arabic Ghoul and its Western Transformation." Folklore 120 (December 2009), 291-306.

Alden's Cyclopedia of Natural History 2. New York: John B. Alden, 1893.

Aldrovandi, Ulisse. Ornithologiae, hoc est de avibus historiae libri XII (Ornithologiae, this is about birds history books 12). Bonogna: A Sienese Franciscan, 1599.

Anonymous. "The Mysterious Stranger." Chambers's repository of instructive and amusing tracts 4. Edinburgh: William and Robert Chambers, Tract 62, 1854. Retrieved from https://bit.ly/2zZbZcC.

Anonymous. Death Watch. New-York Historical Society: October 28, 2011.

Ashley, Mike. Vampires: Classic Tales. Mineola: Dover Publications, Inc., 2011.

Barber, Paul. Vampires, Burial, and Death: Folklore and Reality. New Haven: Yale University Press, 1988.

Baring-Gould, Sabine. "Margery of Quether." The Cornhill Magazine (April 1884).

Belwood, Jacqueline J., and Patricia A. Morton. "The truth about the bats people love to hate is even more fascinating than the myths...." BATS Magazine 9, no. 1 (Spring 1991).

Benson, Elizabeth P. "Bats in South American Folklore and Ancient Art." BATS Magazine 9, no. 1 (Spring 1991).

"Bats in South American Folklore and Ancient Art." Andean Past 1 (1987).

Bird, Isabella Lucy. The Golden Chersonese and the Way Thither. New York: G. P. Putnam's Sons, 1883. 
Bowen, Courthope H. ed. "Simple English Poems: English Literature for Junior Classes." In Four Parts. London: C. Kegan Paul and Co., 1879.

Boylan, Andrew. "Stoker and the Bat." Vamped (April 1, 2014). . Media Vampire: A Study of Vampires in Fictional Media, Lulu.com. (2012).

Braddon, Mary Elizabeth. "Good Lady Ducayne." The Strand Magazine: An Illustrated Monthly 11 (February 1896).

Brown, David E. Vampiro: The Vampire Bat in Fact and Fantasy. Silver City: High-Lonesome Books, 1994.

Bunson, Matthew. The Vampire Encyclopedia. New York: Crown Trade Paperbacks, 1993.

Burton, Richard F. "Vikram and the Vampire; or, Tales of Indian Devilry." Fraser's Magazine for Town and Country 77 (April 1868).

Carlisle, Thomas. "Natural History: Bats." The Juvenile Instructor and Companion 17-5 (1866).

Carlyle, Thomas. "Dr. Francia." The Foreign Quarterly Review 31 (July 1843).

Copper, Basil. The Vampire in Legend and Fact. New York: Citadel Press Book, 1973.

Crawford, Heide. The Origins of the Literary Vampire. Lanham: Rowman \& Littlefield, 2016.

d'Anghiera, Pietro Martire. De Orbe Novo: The Eight Decades of Peter Martyr D'Anghera, 2 vols. Translated by Francis Augustus MacNutt. New York: The Knickerbocker Press, 1963.

Dante. Inferno. Translated by Carlyle John Aitken. London: J. M. Dent \& Co., 1904.

Dalby, Richard. Dracula's Brood. New York: Dorset Press, 1987.

Darwin, Charles. Narrative of the surveying voyages of His Majesty's Ships Adventure and Beagle between the years 1826 and 1836, describing their examination of the southern shores of South America, and the Beagle's circumnavigation of the globe. Journal and remarks. 1832-1836. London: Henry Colburn, 1839.

de Azara, Felix. Essais sur l'histoire naturelle des quadrupèdes de la province du Paraguay (Essays on the natural history of quadrupeds in the province of Paraguay). Paris: Charles Pogens, 1801.

de la Condamine, Charles Marie. Relation abrégée d'un voyage fait dans l'interieur de l'Amérique méridionale (Abbreviated relationship of a trip made in the interior of South America). Paris: Veuve Pessot, 1745.

Dickens, Charles. Bleak House. London: Bradbury \& Evans, 1853.

Ditmars, Raymond Lee, and Arthur M. Greenhall. "The vampire bat; a presentation of undescribed habits and review of its history." Zoologia: Scientific Contributions of the New York Zoological Society 19, no. 2 (April 1935).

Dobson, G. E. "Vampire." Encyclopaedia Brittanica 24. New York, 1888.

Dumas, Alexandre. The Return of Lord Ruthven the Vampire. Translated by Frank J. Morlock. Trazana: Hollywood Comics, 2004. 
Edwards, George. A Natural History of Birds. London: College of Physicians, 1751.

Frayling, Christopher. Vampyres: Lord Byron to Count Dracula. London: Faber and Faber, 1991.

French, Barbara. "False Vampires and Other Carnivores: A glimpse at this select group of bats reveals efficient predators with a surprisingly gentle side ...." BATS Magazine 15, no. 2 (Summer 1997).

Georges-Louis Leclerc, Comte de Buffon. Histoire Naturelle, générale et particulière, avec la description du Cabinet du Roi (Natural History, general and particular, with the description of the Cabinet of the King) 10, 1763.

Greenhall, Arthur M., Gerhard Joermann, and Uwe Schmidt. "Desmodus rotundus." Mammalian Species no. 202 (December 1983), 1-6.

Gumilla, Joseph. El Orinoco ilustrado, y defendido: historia natural, civil, y geográfica de este gran río y de sus caudalosas vertientes (The Orinoco illustrated, and defended: natural, civil, and geographical history of this great river and its mighty slopes). Madrid: Manuel Fernandez, 1745.

Hardy, Phil, Tom Milne, and Paul Willemen. ed. Overlook Film Encyclopedia: Horror. Overlook Press, 1995.

Hogg, Anthony. "Bats Before Bram." The Vampirologist (April 6, 2014). Retrieved from https://bit.ly/2lMIQas.

_. "Bats Where They Don't Belong." Diary of an Amateur Vampirologist (January 25, 2011). Retrieved from https://bit.ly/2tMgK3A.

Holmes, Oliver Wendell. "Farewell to Agassiz." The Atlantic Monthly-A Magazine of Literature, Science, Art, and Politics 16, no. 97 (November 1865).

Ito, Fernanda, Enrico Bernard, and Richard A. Torres. "What is for Dinner? First Report of Human Blood in the Diet of the Hairy-Legged Vampire Bat Diphylla ecaudata." Acta Chiropterologica 18, no. 2 (December 2016).

Kotowski, Oliver. ed. Lasst die Toten ruhen: Deutsche Vampirgeschichten aus dem 19 (Let the dead rest: German vampire stories from the 19th). Jahrhundert, Stolberg: Atlantis Verlag, 2012.

Lee, Sarah. Anecdotes of the Habits and Instincts of Birds, Reptiles, and Fishes. London: Grant \& Griffith, 1853.

Anecdotes of the Habits and Instincts of Animals. London: Griffith, Faran, Okeden, \& Welch, 1852.

Le Fanu, J. Sheridan. "Carmilla." The Dark Blue 2 (December 1871).

Link, Luther. The Devil: A Mask Without a Face. London: Reaktion Books, 2004.

Linnaeus, Carl. Systema Naturae, 10 ${ }^{\text {th }}$ ed. Stockholm: Salvius, 1758.

Lydekker, Richard. ed. The Royal Natural History 1. London: Frederick Warne \& Company, 1893-94.

MacNally, Raymond, and Radu Floresçu. "Vampirism: Old World Folklore." In The Vampire in Slavic Cultures, edited by Thomas J. Garza. San Diego: University Readers, 1994/2009. 
Melton, Gordon J. The Vampire Book: The Encyclopedia of the Undead. Michigan: Visible Ink Press, 2011.

Miller, Elizabeth. "Coitus Interruptus: Sex, Bram Stoker, and Dracula." Romanticism on the Net 44 (November 2006a). " "Getting to Know the Un-Dead: Bram Stoker, Vampires and Dracula." In Vampires, Myths and Metaphors of Enduring Evil, edited by Peter Day. New York: Rodopi Press, 2006b.

__. A Dracula Handbook. Xlibris, 2005.

. Dracula: Sense and Nonsense. Essex: Desert Island Books, 2000.

__. "Bats, Vampires \& Dracula." The Night Flyer: News for the Friends of Florida's Bats 3, no. 4 (Fall 1998).

Napier, Charles Ottley Groom. The Book of Nature and the Book of Man. London: John Camden Hotten, 1870.

Nizet, Marie. Captain Vampire. Translated by Brian Stableford. Tarzana, CA: Black Coat Press, 2007; first published 1879.

Oinas, Felix. "East European Vampires." In The Vampire: A Casebook, edited by Alan Dundes. Madison: University of Wisconsin Press, 1998.

Pennant, Thomas. Synopsis of Quadrupeds. Chester: J. Monk, 1771.

Perkovski, Jan. Vampires of the Slavs. Cambridge, Mass: Slavika Publishers, Inc., 1976.

Pettit, Edward. Varney the Vampire by James Malcolm Rymer. Retrieved from https://bit.ly/2KBgk9Y.

Platts, John Tompson. The Baital Pachchisi, or, The Twenty-five Tales of a Sprite. London: Wm. H. Allen, 1871.

Rossback, Susanne. Des Dandys Wort als Waffe: Dandyismus, narrative Vertextungsstrategien und Geschlechterdifferenz im Werk Jules Barbey d'Aurevillys (The dandy's word as a weapon: Dandyism, narrative strategies of articulation and gender difference in the work of Jules Barbey d'Aurevilly). Tübingen: Max Niemeyer Verlag, 2002.

Saint Basil (Bishop of Caesarea). Commentary on the Prophet Isaiah. Texts and Studies in the History of Theology 7. Translated by Nicolai A. Lipatov, edited by Kinzig Wolfram and Vinzent Wolfram. Cambridge: Edition Cicero, 2001.

Schomburgk, Richard. Travels in British Guiana During the Years 1840-1844. Leipzig: J. J. Weber, 1847.

Schutt, Bill. "The Curious, Bloody Lives of Vampire Bats." Natural History Magazine 117, no. 9 (November 2008). Retrieved from https://bit.ly/2KuGues.

Sherwood, M. E. W. Review of Boucicault's "The Phantom." In Actors and Actresses of Great Britain and the United States: From the Days of David Barrick to the Present Time 5, edited by Brander Matthews and Laurence Hutton. New York: Cassell \& Company, 1886/1875.

Skal, David J. Vampires: Encounters with the Undead. New York: Black Dog \& Leventhal, 2001. 
Stedman, John. Narrative, of a Five Years' Expedition, Against the Revolted Negroes of Surinam, in Guiana, on the Wild Coast of South America; from the Year 1772, to 1777: Elucidating the History of that Country, and Describing Its Productions, Viz. Quadrupedes, Birds, Fishes, Reptiles, Trees, Shrubs, Fruits, $\mathcal{E}$ Roots; with an Account of the Indians of Guiana, E Negroes of Guinea 2. London: J. Johnson and J. Edwards, 1796.

Stephens, Henry L. The Comic Natural History of the Human Race. Philadelphia: S. Robinson, 1851.

Stoker, Bram, and Valdimar Ásmundsson. Powers of Darkness; The Lost Version of Dracula. Translated by Hans Corneel de Roos. New York: Overlook Duckworth, 2017.

Stoker, Bram, and Christopher David. Dracula: Scholar's Edition. Selfpublished, Google Play, 2015.

Stoker, Bram, Richard Eighteen-Bisang, and Elizabeth Miller. Bram Stoker's Notes for Dracula: A Facsimile Edition. Jefferson, North Carolina: McFarland \& Company, 2008.

Stoker, Bram, and Leslie S. Klinger. The New Annotated Dracula. New York: W. W. Norton \& Co., 2008.

Stoker, Bram, Nina Auerbach, and David J. Skal. Dracula: A Norton Critical Edition. London: W. W. Norton \& Co., 1997.

Stoker, Bram, and Clive Leatherdale. Dracula Unearthed. Westcliff-on-Sea: Desert Island Books, 1988.

Stoker, Bram, and Leonard Wolf. The Annotated Dracula. New York: Ballentine Books, 1975.

Stoker, Bram. Dracula. New York: Grosset and Dunlap, 1897. Retrieved from https://bit.ly/2t3EMpw.

Stuart, Roxana. Stage Blood: Vampires of the 19th Century Stage. Bowling Green, Ohio: Bowling Green State University Popular Press, 1994.

Tenniel, John. The Irish Vampire, Punch, or The London Charivari 39 (October 17, 1885).

Tertullian. Apologeticus. Ante-Nicene Christian Library 11. Alexander Roberts and James Donaldson. Edinburgh: T. \& T. Clark, 1869.

"They Burned the Vampire." Healdsburg Tribune, Enterprise and Scimitar 14 (June 22, 1893). Retrieved from https://bit.ly/21PN3ua.

Ulrich, Heinrich. "Manor." In Lasst die Toten ruhen: Deutsche Vampirgeschichten aus dem 19 (Let the dead rest: German vampire stories from the $19^{\text {th }}$ ), edited by Oliver Kotowski. Jahrhundert, Stolberg: Atlantis Verlag, 2012.

Veckenstedt, Edmund. Wendische Sagen, Märchen und abergläubische Gebräuche (Wendish legends, fairy tales and superstitious customs). Graz: Leuschner and Lubensky, 1880.

von Spix, Johann. Simiarum et Vespertilionum Brasiliensium species novae ou Histoire Naturelle des espècies nouvelles de singes et de chauves-souris observées et recueillies pendant le voyage dans l'interieur du Brésil exécuté par ordre de $S$ 
M Le Roi de Bavière dans les années 1817, 1818, 1819, 1820 (Simiarum and Vespertilionum Brasiliensium species novae or Natural History of the new species of monkeys and bats observed and collected during the journey in the interior of Brazil executed by order of S M The King of Bavaria in the years 1817, 1818, 1819, 1820). Munich: Typis Francisci Seraphi Hybschmanni, 1823.

von Wachsmann, Carl Adolf. "Der Fremde." Erzälungen und Novellen 3: 7. Leipzig: Carl Jocke von Wachsmann 1844. Retrieved from https://bit.ly/2JyrIPe.

Wallace, Alfred Russel. A Narrative of Travels on the Amazon and Rio Negro: With an Account of the Native Tribes, and Observations on the Climate, Geology, and Natural History of the Amazon Valley. London: Reeve \& Co., 1853.

Waterton, Charles. Essays on natural history, chiefly ornithology. London: Longman, Orme, Brown, Green and Longmans, 1838.

. Wanderings in South America, in the North West of the United States, and the Antilles, in the Years 1812, 1816, 1820, and 1824. London: J. Mawman, 1825.

Wood, William. Zoography, Or, The Beauties of Nature Displayed: In Select Descriptions from the Animal, and Vegetable, with Additions from the Mineral Kingdom Systematically Arranged. London: Dadell and Davies, 1807.

Young, Arthur. "Pepopukin in Corsica." In The Stanley Tales 1, edited by Ambrose Marten. London: W. Morgan, 1826. 
